\title{
FIRST RECORD OF SCLERODERMA POLYRHIZUM PERS. (GASTEROMYCETES) FROM BRAZIL ${ }^{1}$
}

\author{
Iuri Goulart Baseia ${ }^{2}$ \\ Adauto Ivo Milanez ${ }^{2}$
}

Recebido em 18/11/1999. Aceito em 03/03/2000

\begin{abstract}
RESUMO - (Primeiro registro de Scleroderma polyrhizum Pers. (Gasteromycetes) para o Brasil). Scleroderma polyrhizum, um gasteromiceto ectomicorrízico, é registrado pela primeira vez para o Brasil, crescendo sob Caryocar brasiliense Camb. (Caryiocaraceae) espécie arbórea comum e nativa da vegetação de cerrado brasileiro. Os caracteres macro e microscópicos foram descritos a partir de basidiocarpos frescos e secos, segundo a metodologia tradicional utilizada em estudos taxonômicos de Gasteromycetes. As características do material analisado foram similares à descrição original fornecida por Persoon. Todo material coletado estava associado a raízes de $C$. brasiliense.
\end{abstract}

Palavras-chave - Gasteromycetes, Scleroderma polyrhizum, taxonomia, ectomicorriza

\begin{abstract}
First record of Scleroderma polyrhizum Pers. (Gasteromycetes) from Brazil). The ectomycorrhizal, gasteroid fungus, Scleroderma polyrhizum is recorded from Brazil for the first time, growing under Caryocar brasiliense Camb. (Caryocaraceae) a widespread native tree of the Brazilian "cerrado" vegetation. Macro and microscopic features were described using basidiocarps from fresh and dried material treated according to the traditional methodology for Gasteromycetes. The characteristics of the material were close to those of the original description given by Persoon. All material collected was associated with roots of $C$. brasiliense.
\end{abstract}

Key words - Gasteromycetes, Scleroderma polyrhizum, taxonomy, ectomycorrhiza

\section{Introduction}

The content of this paper constitutes a portion of extensive studies concerning the gasteroid mycota from Brazilian "cerrado" vegetation, including the "Reserva Ecológica de Jataî" (State of São Paulo).

The genus Scleroderma was proposed by Persoon (1801) and later revised by Guzmán (1970), who accepted 21 species. This genus is caracterized by a thick and microscopically vaguely differentiated peridium and dusty gleba with age. According to Harley \& Smith (1983) and Richter (1992) this taxon usually forms an ectomycorrhizal association.

At present there are but few studies on Gasteromycetes. From Brazil Scleroderma has small representativity yet and only $S$. albidum Pers, $S$. citrinum Pers., S. verrucosum (Bull.) Pers., S. vulgare Horn. and $S$. tenerum B. et C.

1 Parte da Tese de Doutorado do primeiro Autor. Bolsista da CAPES

2 Instituto de Botânica, C. Postal 4005, CEP 01061-970, São Paulo, SP, Brasil 
were recorded by Rick (1961) and Bononi et al. (1981).

\section{Material and methods}

Specimens of Scleroderma were collected during the rainy season of 1999 (January to March), in the "Reserva Ecológica de Jataî" (State of São Paulo), located in an area of $4,532.18$ ha, at $21^{\circ} 33^{\prime}-21^{\circ} 37^{\prime} \mathrm{S}$ and $47^{\circ} 45^{\prime}$ $46^{0} 51$ 'W. Climatic conditions are of the AW type, according to the Köppen System.

Hand-cut sections of dried material were mounted for microscopical examination in Melzer's reagent, $5 \% \mathrm{KOH}$, water or cotton blue (Toledo 1993). Basidiospore measurements included the ornamentation. Permanent microscopic slides were made using PVL resin (alcohol polyvinilic and lactophenol), according to Trappe \& Schenck (1982). In our fieldwork and mycorrhizal analysis, we used the methods of Zak (1973) and Schenck (1982), respectively. Colour terms in parenthesis are those of Kornerup \& Wanscher (1978), abreviated as KW. The material was included at the Herbarium of the Instituto de Botânica, Seção de Micologia e Liquenologia (SP), abbreviated by acronyms according to the Index Herbariorum (Holmgren et al. 1990).

\section{Results and discussion}

Scleroderma polyrhizum Pers., Syn. Meth. Fung., p. 156, 1801.Type: lost

Neotype: Bartlett 1600 (MICH)

Basionym: Lycoperdon polyhrizon Gmel., Syst. Nat., 2, p. 1464, 1796.

Sclerangium polyhrizum (Pers.) Lév., Ann. Sci. Natur., 3-9: 130, 1848.

Lycoperdastrum rotundum majus Mich., Nov. Plant. Gen., p. 219, 1729;

Scleroderma geaster Fr., Syst. Myc., 3, p. 46, 1829;

Sterrebeckia geaster (Fr.) Fr., Ac. Acad. Sc. Holm., 1848.

(Synonyms according to Gusmán (1970)
Fig. 1-5

Gasterocarp 2-4cm broad, subpiriform, sessile, dark brown (KW-6F6). Peridium triplex up to $7 \mathrm{~mm}$ when fresh, becoming much thinner when dry, hard, tough, squamous, usually dehiscing by irregular splitting, from the apex downwards into unequal lobes. Exoperidium hymeniform, with thin walled hyphae, hyaline, 6-7.4-8.3 x 4.5-5.7-6.2 $\mathrm{mm}$. Mesoperidium with interwoven hyphae, which are thick-walled, brown, 4-6mm diam. Endoperidium slightly differentiated, thin-walled, hyaline, $2-3 \mathrm{~mm}$ diam. Gleba pulverulent, dark grey (KW-3F1). Basidiospore subglobose, 6-7mm diam., brown, finely echinulate. Capillitium absent.

Habitat: On sandy soil.

Distribution: Africa (Bottomley 1948), China (Liu 1984), England (Demoulin \& Marriott 1981), France (Calonge \& Demoulin 1975), Japan (Hara 1954), USA (Coker \& Couch 1928; Guzmán 1970).

Material examined: BRAZIL. São Paulo: Luís Antônio, Estação Ecológica de Jataí, 28/I/1999, Baseia 428, (SP 307298); 24/II/1999, Baseia 443, (SP 307299); 8/III/1999, Baseia 461, (SP 307300).

Material additional examined (donated to SP Herbarium): UNITED STATES OF AMERICA. Ohio: Fort Hill State Memorial, Highland Co., 3/VII/1970, W. B. \& V. G. Cooke 41950 (SP 141511).

S. polyrhizum is characterized by the dark brown colour, usually rugose, hard peridial wall, stellate manner of dehiscence, and often finally empty peridium due to the disappearance of the gleba. It differs from $S$. flavidum and $S$. texense, which dehisces in a similar manner, in its usually bigger size, rugose peridium and the subglobose basidiospores with smaller spines.

The carpophores of this species grow solitary during the rainy seasons, from the end of January to the beginning of March, associated with Caryocar brasiliense Camb. (Caryocaraceae), a widespread native tree of this biome, 

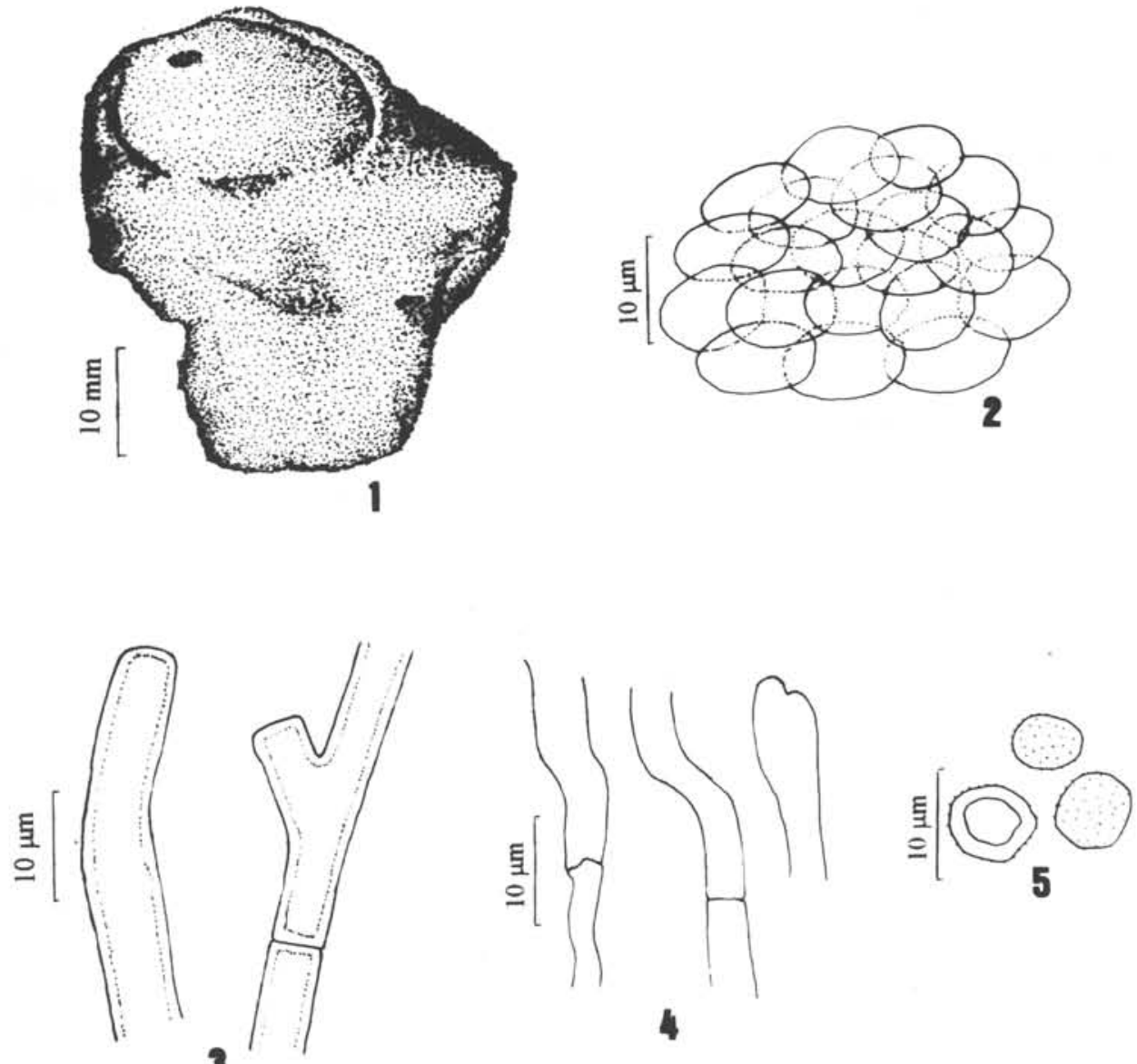

Figure 1-5. Scleroderma polyrhizum Pers. 1. gastrocarp (general aspect before dehiscence); 2. hyphae of exoperidium; 3. hyphae of mesoperidium; 4 . hyphae of endoperidium; 5 . basidiospores.

thus exhibiting ectomycorrhizal association. This simbiotic relationship was sustained by rhizomorphs of $S$. polyrhizum that were aggregated with roots of this tree. Mantle and Hartig net, characteristics of ectomycorrhiza, were detected by microscopic analysis. There is no published register of the mutualistic association between these taxa.

\section{References}

Bononi, V. L.; Trufem, S. F. \& Grandi R. A. 1981. Fungos macroscópicos do Parque Estadual das Fontes do Ipiranga, São Paulo (SP), Brasil, depositados no Herbário do Instituto de Botânica. Rickia 9: 37-53.
Bottomley, A. M. 1948. Gasteromycetes of South Africa. Bothalia 4: 473-810.

Calonge, F. D. \& Demoulin, V. 1975. Les Gastéromycètes d'Éspagne. Bulletin Societé Mycologique du France 91(2): 247-292.

Coker, W. C. \& Couch, J. N. 1928. The Gasteromycetes of the Eastern United States and Canada. The University of North Carolina Press, Chapel Hill.

Demoulin, V. \& Marriott, J. V. R. 1981. Key to the Gasteromycetes of Great Britain. Bulletin 15: 37-56.

Guzmán, G. 1970. Monografia del género Scleroderma Pers. emend. Fr. (Fungi-Basidiomycetes). Darwiniana 16(1-2): 233-407.

Hara, K. 1954. A list of Japanese fungi hitherto know. The Mycological Society of Japan.

Harley, J. L. \& Smith, S. E. 1983. Mycorrhizal Symbiosis. Academic Press, London. 
Holmgren, P. K.; Holmgren, N. H. \& Barnett, L. C. 1990. Index Herbariorum, part I, The Herbaria of the World, 8th edn. Reg. Veg., New York Botanical Garden, Bronx, New York.

Kornerup, A. \& Wanscher, J. E. 1978. Methuen Handbook of Colour, Methuen, London.

Persoon, D. C. 1801. Synopsis Methodica Fungorum. Gotinga.

Richter, D. L. 1992. Six species of Scleroderma (Gasteromycetes, Sclerodermatales) described from pure cultures. Mycotaxon 45: 461-471.

Rick, J. 1961. Basidiomycetes Eubasidii no Rio Grande do Sul. Theringia 9: 451-480.

Schenck, N. C. 1982. Methods and principles of micorrhizal research. The American Phytopathological Society, St. Paul.
Toledo, L. D. 1993. Gasteromycetes (Eumycota) del Centro Oeste de la Argentina 1. Analisis critico de los caracteres taxonomicos, clave de los generos y orden Podaxales. Darwiniana 32(1-4): 195-235.

Trappe, J. M. \& Schenck, N. C. 1982. Taxonomy of the fungi forming endomycorrhizae. Pp. 1-9. In: N. C. Schenck (Ed.). Methods and principles of mycorrhizal research. The American Phytopathological Society, St. Paul.

Zak, B. 1973. Classification of ectomycorrhizae. Pp. 4378. In: G. C. Marks, T. T. Kozlowski (Eds.), Ectomycorrhizae. Academic Press, New York. 